\title{
Geology of Bajalia Anticline of the Low Folded Zone of Iraq
}

\author{
Wathiq Abdulnaby ${ }^{1}$, Maher Mahdi ${ }^{1, *}$, Rafed Al-Muhamed ${ }^{1}$, Nagham Darweesh $^{1}$, \\ Ahmed Hashoosh ${ }^{2}$ \\ ${ }^{1}$ Dept. of Geology, College of Science, University of Basrah \\ ${ }^{2}$ Groundwater Authority, Ministry of Water Resources, Maysan Governorate \\ Corresponding Author:maher_mandeel@yahoo.com
}

\begin{abstract}
Bajalia Anticline is located about $60 \mathrm{~km}$ northeast of central Amarah city in the Al-Teeb area near the Iraq-Iran border. Field and laboratory works were conducted to study topography, geomorphology, stratigraphy, and structural geology of Bajalia Anticline. The Anticline has a longitudinal shape with about $29 \mathrm{~km}$ in length and $5-7 \mathrm{~km}$ in width. Injana, Mukdadiya, and Bai Hassan formations are the three formations that were recognized in the study area. The geometrical structural analysis depicts that the Anticline is non-cylindrical, asymmetrical, close, subhorizontal, steeply inclined, and linear fold. Most of the fractures in the Anticline are joints. These joints were classified based on the tectonics axes, which are $\mathrm{a}, \mathrm{b}$, and $\mathrm{c}$, into $a c, b c$, and hol. A major reverse fault is located at the margin of the southwestern limb parallel to the fold axis with about $25 \mathrm{~km}$ length. This fault is responsible for the vergence of the Anticline and overturned part of the southwestern limb. The Anticline was formed as a result of the collision between the Arabian and Iranian plates during the Late Tertiary. The maximum stress axis, which is caused by collision, is perpendicular to the hinge line. The geometrical and genetic classification indicates that the Anticline was formed by the high folding intensity and with a role of evaporites layers.
\end{abstract}

Keywords: Bajalia anticline; Iraq; low folded zone; upper miocene; Zagros Fold-Thrust belt.

\section{Introduction}

From northeast to southwest, Iraq is divided tectonically into (1) the Zagros Fold-Thrust Belt, which consists of the Thrust, Imbricated, High Folded, and Low Folded Zones, (2) the Mesopotamia Foredeep, and (3) the Inner Platform (e.g. Buday \& Jassim, 1987; Numan, 1997; Jassim \& Göff, 2006; Fouad, 2015) (Figure 1). The contact between the Low Folded Zone and the Mesopotamia Foredeep is represented by several anticlines along NW-SE; these are the Sinjar, Sassan, Sheikh Ibrahim, Addaya, Jawan, Habbariya, Makhul, Himreen North,
Himreen South, Badra, Buzurgan (Bajalia) anticlines. The Low Folded Zone is also called the Zagros Deformational Front and the Zagros Mountain Front (Leturmy \& Robin, 2010).

The Low Folded Zone is characterized by long anticlines with Neogene cores and broad synclines containing thick MioceneQuaternary molasses (Jassim \& Göff, 2006). Tertiary successions are mostly well exposed in the Low Folded Zone within the anticlinal and synclinal structures, while Mesozoic and 
Paleozoic successions are covered (AlMuturi \& Al-Asadi, 2008). The exposed successions include Fat'ha (Middle Miocene), Injana (Upper Miocene), Mukdadiya (Upper Miocene - Pliocene), and Bai Hassan (Pliocene - Pleistocene) formations that were deposited inside the foreland basin of the Arabian Plate (Numan, $1997 \&$ 2000). In the Low Folded Zone, the folds are extremely long and narrow and associated with listric faults. Most of these faults are traceable on the surface for long distances and responsible for the vergence and the asymmetry of the folds. The vergence of anticlines in the Folded Zone is either towards $\mathrm{N}$ and $\mathrm{NE}$ or $\mathrm{S}$ and SW. Some anticlines show a close similarity to the unilateral box fold style. Anticlines are open with wide or sub-rounded hinge zones. Most of the fold limbs are normal but a few are overturned (Numan \& Al-Azzawi, 1993). In the northeastern part of the Low Folded Zone, which is called Kirkuk Block according to Numan (1984), the salt-rich beds in the lower part of Fat'ha Formation have had provided efficient detachment surfaces and acted as an active mobile group (Fouad, 2012). The shortening in the Low Folded Zone varies from 3 to $17 \%$ based on fieldwork studies (Ameen, 1979). Bajalia Anticline is located about $60 \mathrm{~km}$ northeast of the center of Amarah city, Maysan Governorate. The Anticline is surrounded by three other smaller surface anticlines located within the Low Folded Zone of Iraq at the AlTeeb area near the Iraq-Iran border. There is another anticline located to the northwest of Bajalia Anticline called Band, which might belong to the Mesopotamia Foredeep of Iraq. In this case, its existence considers as an exception. Four oilfields are located in the adjacent area around Bajalia Anticline; these are the Abu Ghirab, Fakkah, Halfaya, and Buzurgan (Figure 2). Fouad (2012 \& 2015) named Bajalia Anticline as Buzurgan Anticline, which we think is unsuitable naming because Buzurgan is a name of an oilfield located near Bajalia Anticline. The use of the same name for the oilfield and the Anticline is confusing. Therefore, we attend to name the Anticline by Bajalia, which is the name of a village located within the study area. There is no comprehensive geological study on Bajalia Anticline. However, studies on the hydrogeology, sedimentology, and stratigraphy of the Al-Teeb area were carried out generally (e.g. Alsamaani, 2011; AlAbadi, 2011; Alsaad, 2014; Al-Abadi, 2015). The goal behind field and laboratory works is to study topography, geomorphology, stratigraphy, and structural geology of Bajalia Anticline. Rare studies at study area due to the existence of mines and unexploded bombs.

\section{Methodology}

Field and laboratory works were conducted to study the geology of Bajalia Anticline. The fieldwork was represented by taking the attitudes of beds and fractures along a traverse perpendicular to the hinge line in the middle of the Anticline and other chosen sites. Contacts between formations and lithological units were identified. The thicknesses of these units were calculated to draw a lithological column. Fieldwork took place for five days, mainly focused on describing the lithology, structure and stratigraphy of the geological beds. There is a part of this study located between the IraqiIranian borders, which required a governmental agreement to gather detailed information about the fold at the Iranian side. The other team concentrated on measuring the strike, dip and dip direction for the inclined layers, joints and faults using a geological compass. The total is 67 readings. The laboratory work was represented by using space images to study the geometry, topography, and drainage patterns of the Anticline. Besides that, stereographic 
projections were used to classify the anticline and its fractures.
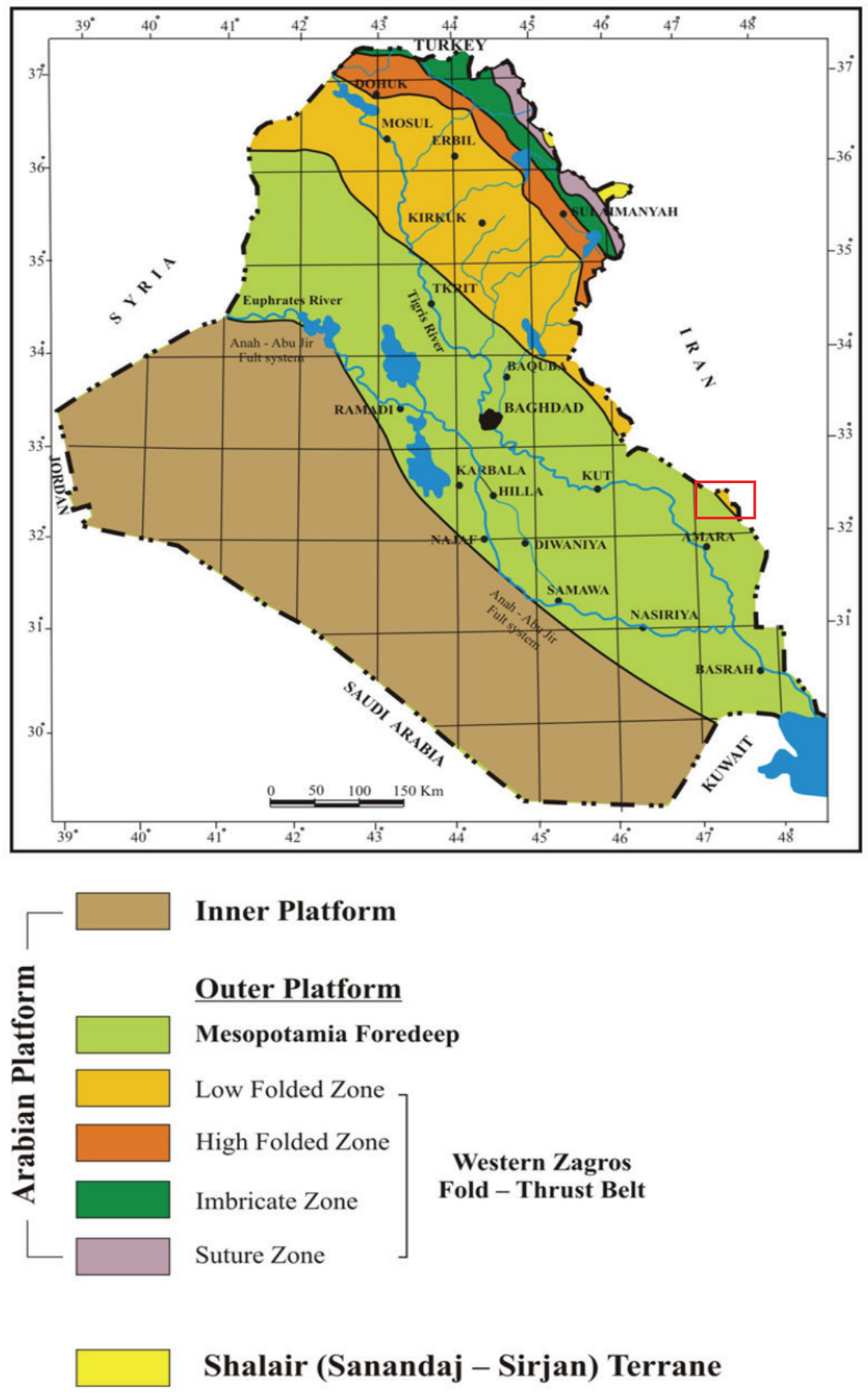

Fig. 1. Tectonic divisions of Iraq after Fouad (2015). Bajalia Anticline is located within the Low Folded Zone inside the red rectangular. 


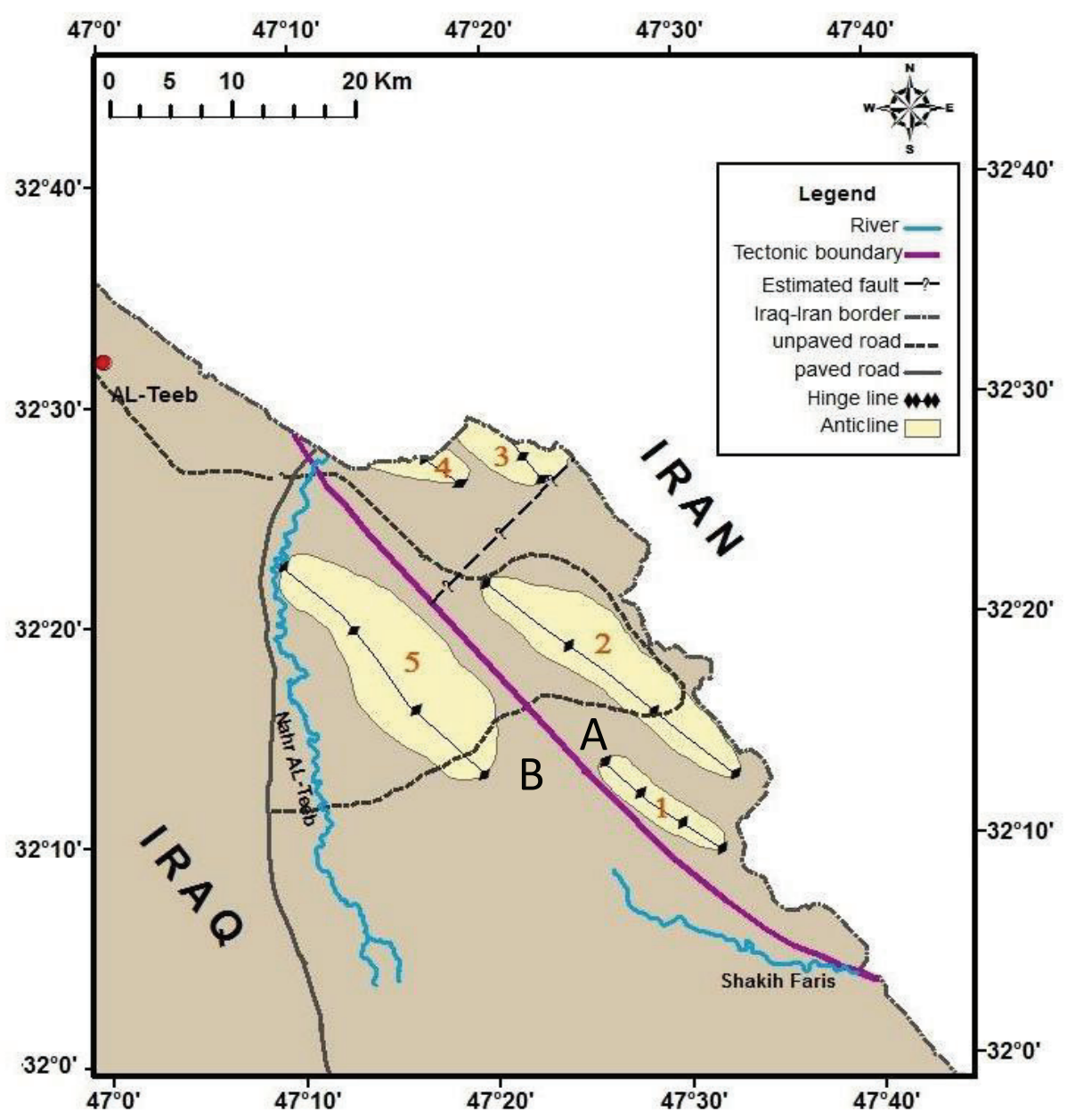

Fig. 2. Geological map of the Al-I eeb Area. A is the Low rolded Lone of the Western Zagros Fold-Thrust Belt. B is the Mesopotamian Foredeep. 1, 3, and 4 are anticlines without names, 2 Bajalia Anticline, 5 Band Anticline.

3. Geometry, Topography, and Geomorphology

Bajalia Anticline has a longitudinal shape with about $28 \mathrm{~km}$ length and $5 \mathrm{~km}$ width; and with northwest to southeast trend, which is the Zagros trend (Figure 3). The length of the $\mathrm{NE}$ limb is about $3.5 \mathrm{~km}$, while the SW limb is about $1.5 \mathrm{~km}$., which means the NE limb is wider than the SW limb. Different huge valleys run through the Anticline perpendicular to the hinge line. These valleys have seasonal water streams that course from the northeast toward the southwest (Figure 5). As well as, the effect of wind that created these valleys and transforms the dust in Iraq and neighboring countries (Al-Dousari \& AlAwadhi, 2012). The contour map in Figure 4 describes the topography of the Anticline and indicates that the range of elevations within the Anticline is about $40 \mathrm{~m}$ at the southwestern limb and $120 \mathrm{~m}$ at the northeastern limb. The Anticline is lying on a surface tilted toward the southwest. 
Therefore, the northeastern limb is higher than the southwestern limb. The complicated contour lines show the differential erosion in the study area that occurs because of the different physical properties of rocks, which are sandstone, siltstone, claystone, and gravel. The southwestern limb of Bajalia Anticline characterizes by sharp and high sandstone ridges with dip angle that ranges from $50^{\circ}$ to $90^{\circ}$, while the northeastern limb has gentle and low sandstone ridges with dip angle that ranges from $20^{\circ}$ to $40^{\circ}$. At the middle of the southwestern limb of the Anticline, beds of the Mukdadiya Formation are overturned, which indicates a high intensity of folding.

Due to the rock properties and dip angles of limbs in Bajalia Anticline, the most common geomorphological units of structural origin are cuestas and hogbacks. The back slope of the cuestas and hogbacks consists of resistant, hard, or well-lithified sandstone, while the front slope consists of weak, or loose claystone and mudstone. Cuestas exist only at the edge of the northeast limb of the anticline due to the low dip angle of beddings planes, which is less than $20^{\circ}$ (Figure 5).

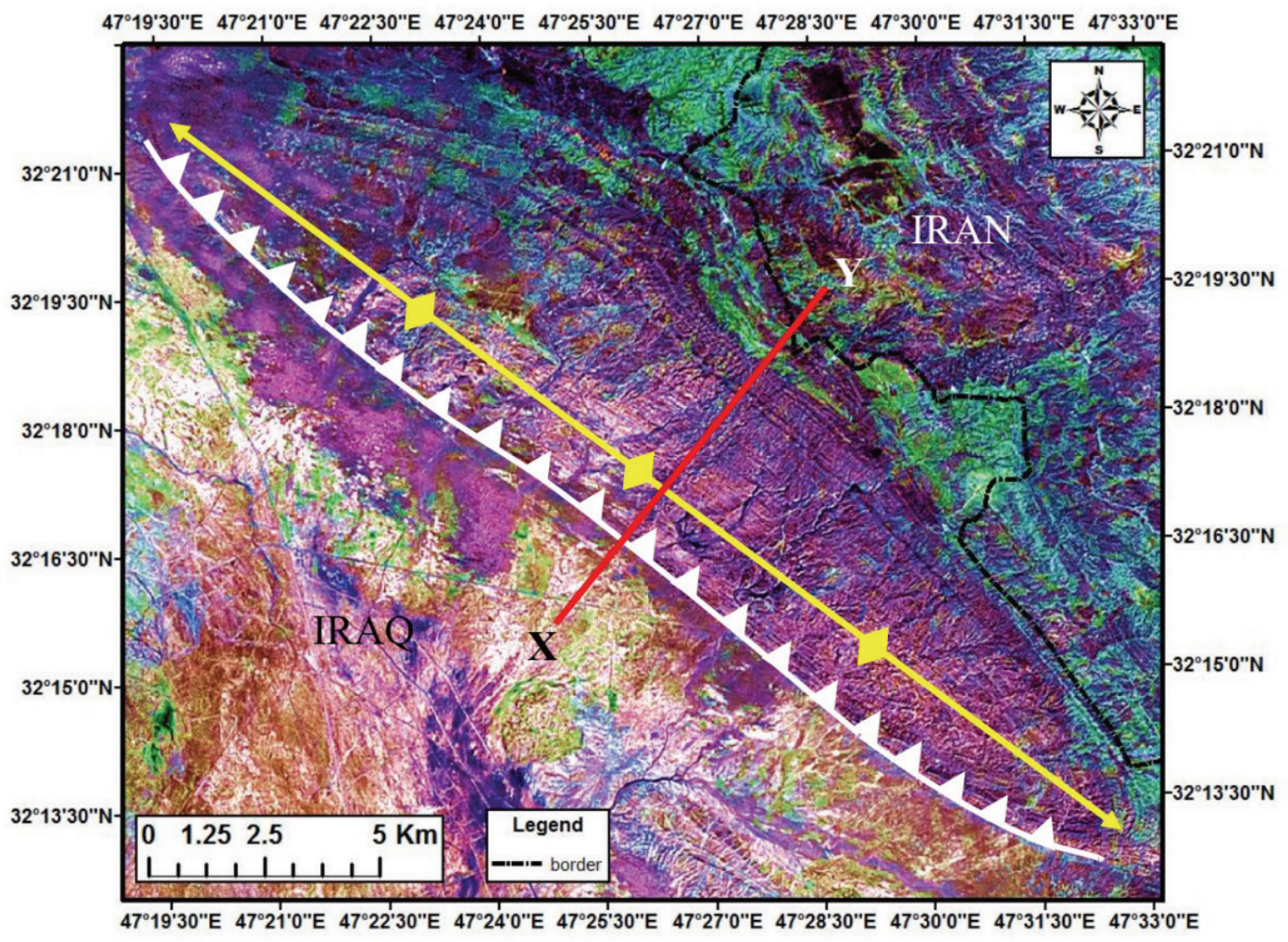

Fig. 3. Satellite image of Bajalia Anticline shows the hinge line in yellow and the reverse fault in white. $\mathrm{X}-\mathrm{Y}$ is a traverse taken perpendicular to the fold axis. 


\section{Stratigraphy}

Three formations are exposed in the Low Folded Zone at the Al-Teeb area; these are the Injana, Mukdadiya, and Bai Hassan formations (Upper Miocene-Pleistocene). Additionally, Quaternary deposits cover many areas that are represented mostly by alluvial fans that were formed due to the seasonal channels that came from Iran to Iraq. The stratigraphic studies of the Bajalia
Anticlines are rare. However, researchers of the Iraq Geological Survey suggested that Mukdadiya and Bai Hassan formations are exposed in the study area (e.g. Barwari, 1991; Barwari et al., 1993; Yacoub, 1993). Other researchers suggested that only the Injana and Mukdadiya Formations are exposed, and Bai Hassan Formation was not recognized (Alsamaani, 2011 and Alsaad, 2014).

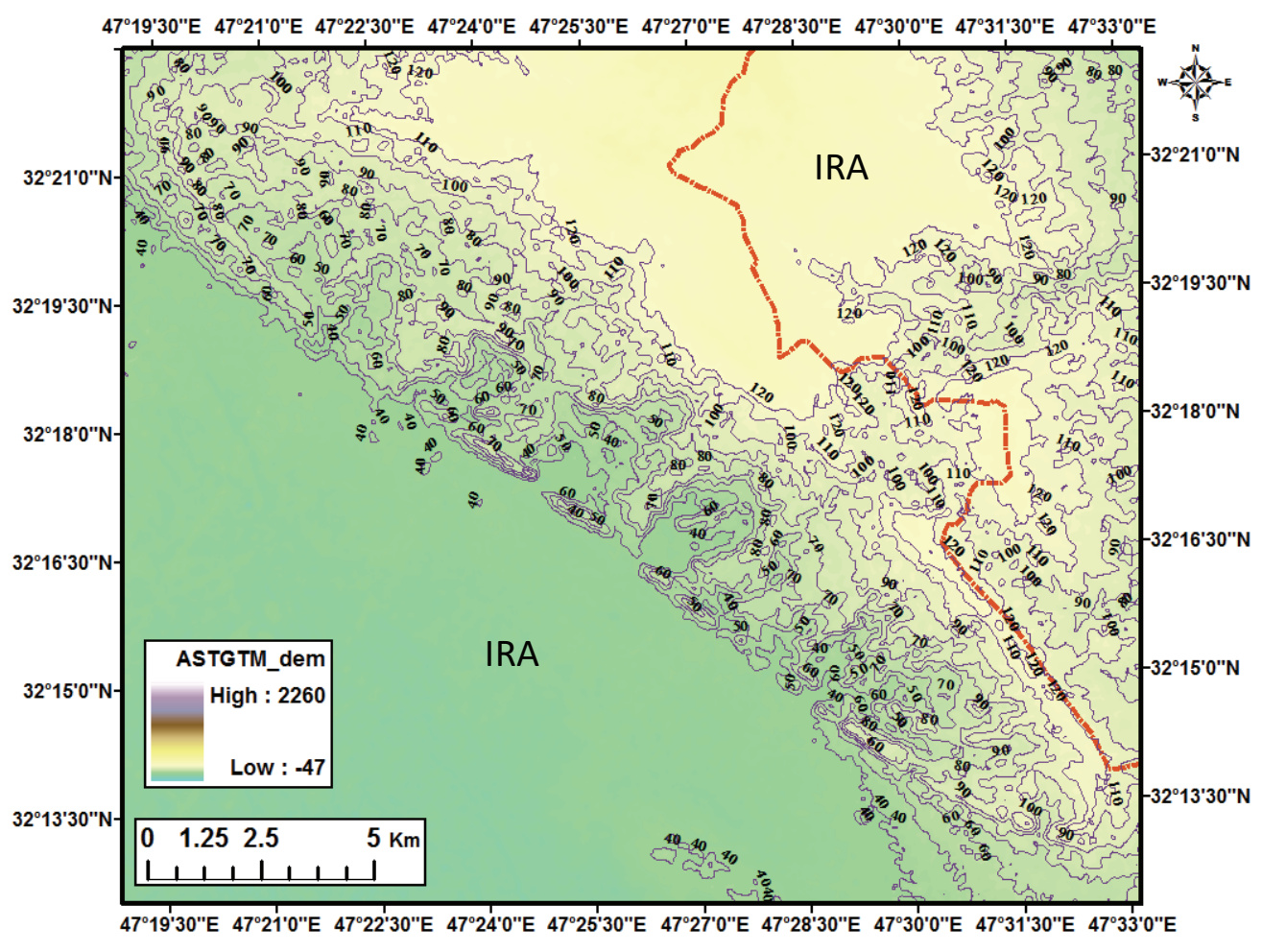

Fig. 4. Topographic map of Bajalia Anticline plotted from the ASTER (GDEM) with a spatial resolution of 15 meters using the Global Mapper version 9.03.

In this study, the three formations were recognized (Figure 6). The Injana Formation exposes at the core of the Anticline, followed by the Mukdadiya Formation at the limbs; and the contact between the two formations is represented by a thin bed of pebbles (around $10 \mathrm{~cm})$ appears in some areas. Bai Hassan
Formation was seen at the first inclined beds at the northwestern limb with 1 to $3 \mathrm{~m}$ thickness and sharp contact with Mukdadiya Formation. Bai Hassan Formation is represented by mixed of boulders, conglomerates, pebbles, with a sand matrix. 

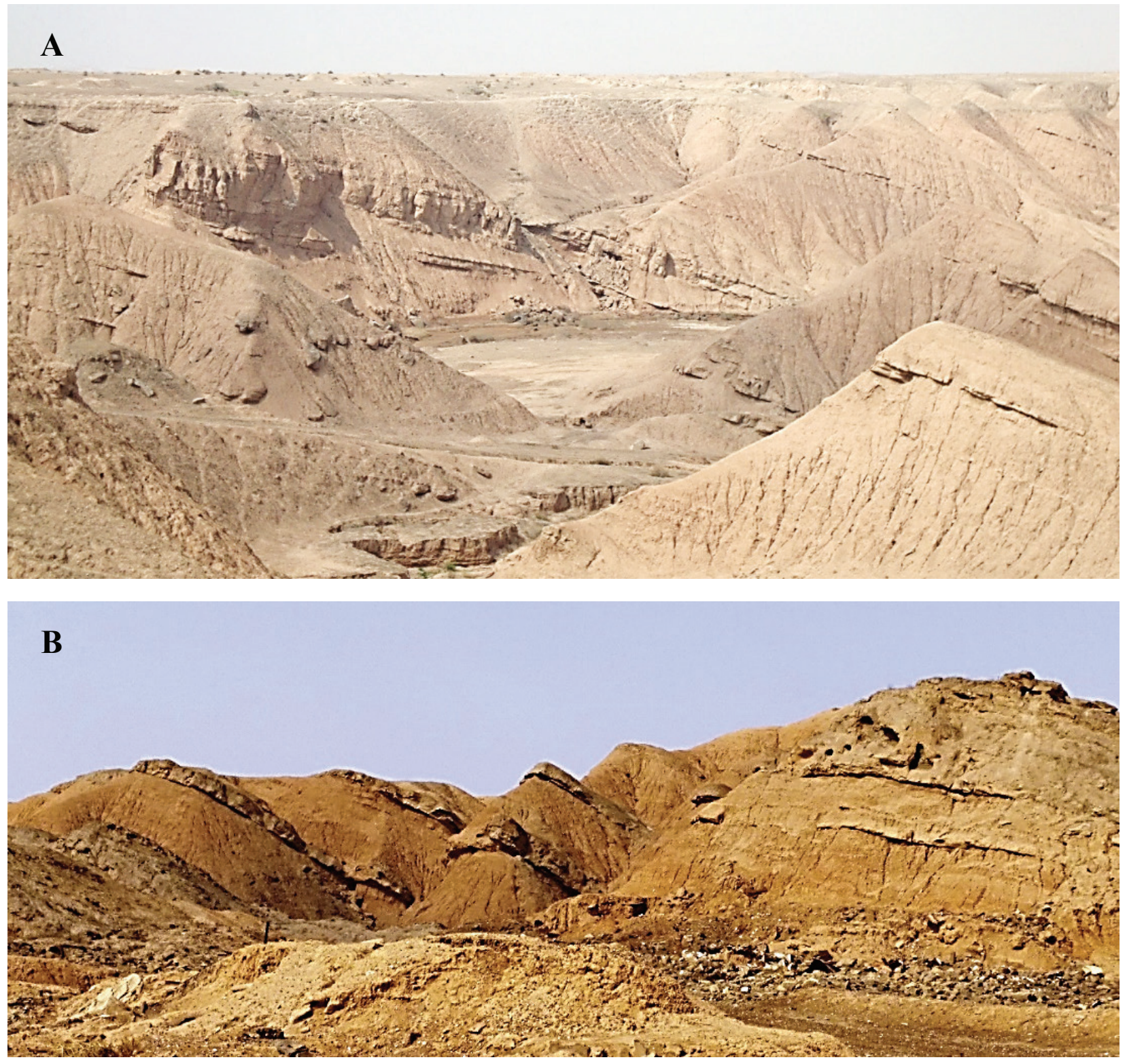

Fig. 5. Cuestas and hogbacks are shown in A and B respectively as geomorphological units in Bajalia Anticline.

These formations represent the depositions of the foreland basin of the Arabian Plate that started to form during the Eocene as a result of the collision between the Arabian and
Iranian Plates and building the Zagros Mountains. A brief description of each formation is in the following. 


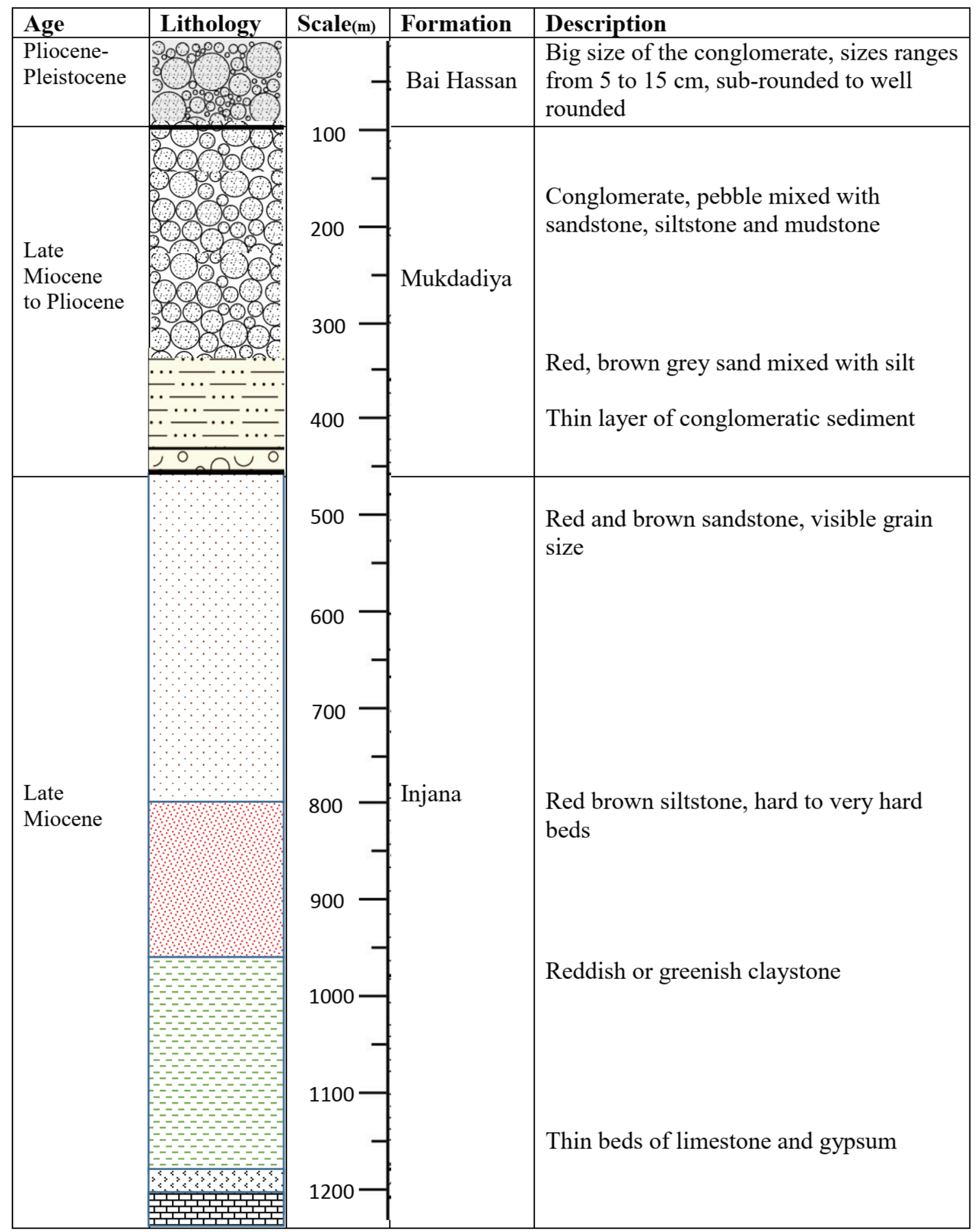


Fig. 6. Stratigraphic column of Bajalia Anticline. The thickness of each formation is calculated from fieldwork, geological maps, and space images.

\subsection{Injana Formation (Late Miocene)}

The age of the Injana Formation (previously Upper Fars and Aghajari Formation in Iran) is difficult to determine because of the scarcity of fossils content. Therefore, the geologists determine the age of the Injana Formation as Late Miocene depending on the stratigraphic position according to the underlying the Fat'ha Formation with the age of Middle Miocene (Bellen et al., 1959; Jassim et al., 1984; and Al-Rawi et al., 1992).

The Injana Formation is the oldest formation exposed at the core of the Anticline. The lower contact of the Injana Formation is conformable with Fat'ha Formation and the upper contact is conformable with Mukdadiya Formation. In general, the lithology of the Injana Formation can be divided into three main units of a coarsening upward cycle; these are from bottom to top: claystone, siltstone and sandstone. At the lower part of the formation, there are thin beds of limestone and gypsum. The sedimentary environment of the formation is a transitional zone from the marine at the lower part to the fluvial environment at the rest of it. The fieldwork depicts that the outcrops of the Injana Formation are located along the hinge. The outcrops of the formation compose of successions of about $1 \mathrm{~m}$ of sandstone bed and several meters of reddish or greenish claystone. The sandstone bed in some cases looks brighter and harder because of cemented material by gypsum.

The lower part of the formation characterizes by the appearance of a thin bed of gypsum with around half-meter thickness that can be the contact with the Fat'ha Formation. The upper contact is gradational and conformable with Mukdadiya Formation. The first appearance of the pebbly sandstone bed is considered the base of the Mukdadiya Formation. The contact seems clear on the southwestern limb with the pebbly sandstone bed, while seems more complicated on the northeastern limb. The thickness of the pebbly layer is about $30 \mathrm{~cm}$.

\subsection{Mukdadiya Formation (Late Miocene - Pliocene)}

Mukdadiya Formation (previously lower Bakhtiari Formation) has no fossils; therefore, the geologists determine the age of Mukdadiya Formation as Late MiocenePliocene (Upper Miocene) depending on the stratigraphic position (Bellen et al., 1959; Jassim et al., 1984; and Al-Rawi et al., 1992). Mukdadiya Formation has many depositional cycles, and each one consists of conglomerate, sandstone, siltstone, and mudstone to claystone. Generally, it represents a fining upward cycle. The typical environment of the Mukdadiya Formation is fluvial that rapidly subsides in the foredeep basin. The thickness of the formation is changeable based on the depositional environment, the shape of the sedimentary basin, and the intensity of weathering and erosion. In the study area, Mukdadiya Formation consists from bottom to top of conglomerate, sandstone, siltstone, and claystone with a total thickness of about $80 \mathrm{~m}$. The conglomerate beds compose of different sizes of pebbles that reach up to $8 \mathrm{~cm}$ in length. The sandstone beds represent the thickest layer in the formation that reaches $50 \mathrm{~m}$. It is rich in the sedimentary structures that concentrate in this unit such as crossbedding, clay balls, trough, graded grain beds, channeling, and worm tubes or burrows. Siltstone beds have less thickness 
that is variable from 0.3 to $5 \mathrm{~m}$. The claystone beds are brown beds with a thickness between 1 to $10 \mathrm{~m}$. This bed has joints and veins filled with gypsum.

\subsection{Bai Hassan (Pliocene - Pleistocene)}

Bai Hassan Formation (previously Upper Bakhtiari) has no accurate age until now. However, many researchers suggested the age Pliocene-Pleistocene (Jassim et al., 1984; Al-Rawi et al., 1992; Sissakian \& Al-Jiburi, 2014). Bai Hasan Formation is rarely exposed in the study area. Most of the formation is eroded and only 1 to $3 \mathrm{~m}$ thickness was identified. The large conglomerates form the contact between the Mukdadiya and Bai Hassan formations. The conglomerate layer is composed of gravels with different sizes ranges from 5 to $15 \mathrm{~cm}$. The conglomerates are surrounded by well rounded, elongated, semispherical shapes, cemented by light yellowish coarse sandstone, some of the gravels formed one compacted bed. The formation was exposed only in the upper part of the Bajalia anticline at the northwestern limb. Bai Hassan Formation has a different inclination compared with the lower formation and occurs as residual beds (Figure 7).
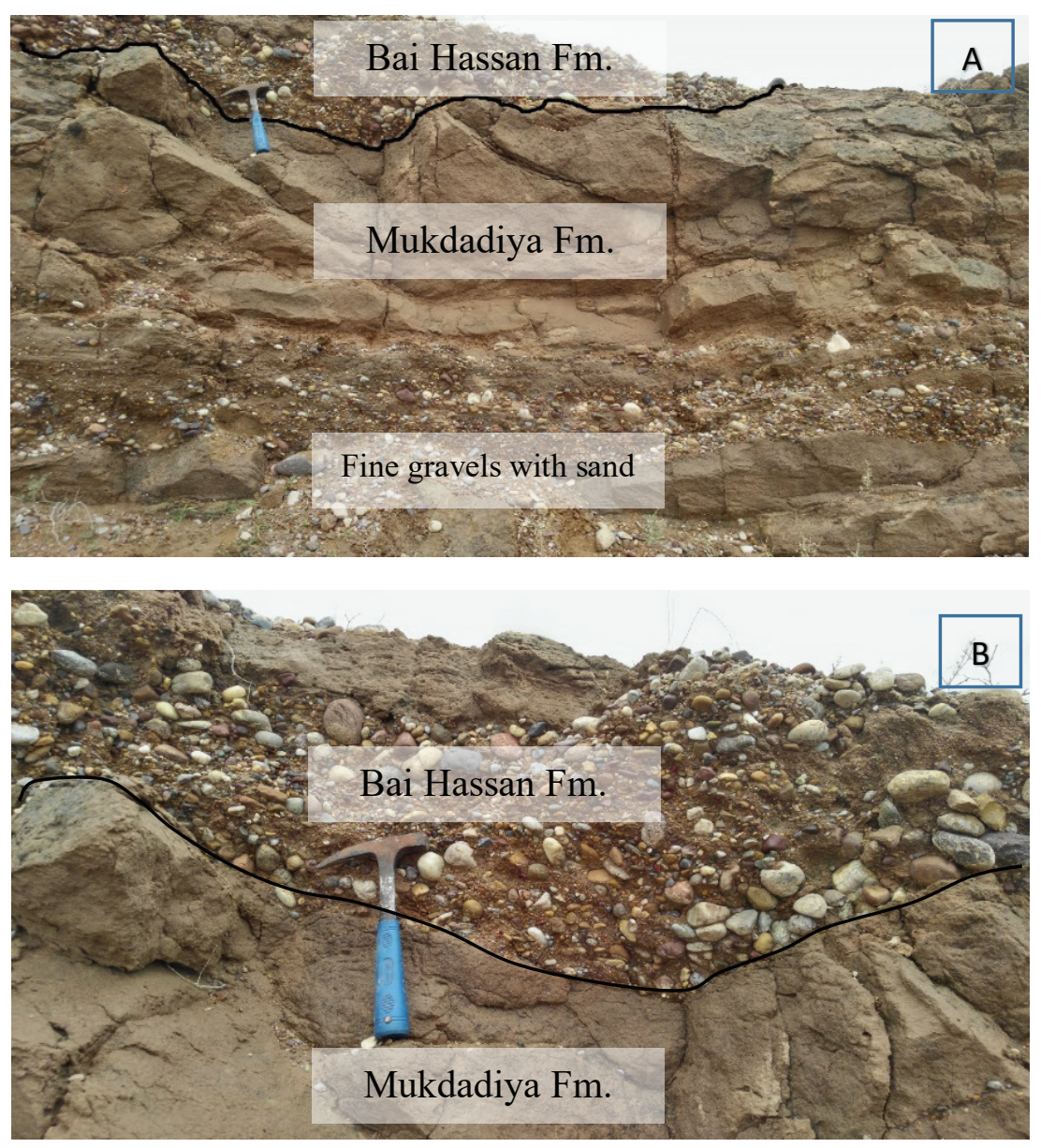

Fig. 7. A. The contact between Bai Hassan and Mukdadiya Formations. B. Magnified view to the difference in the gravels size between the two formations. 


\section{Structural Geology}

Bajalia anticline is formed due to the tectonic collision between the under-riding Arabian and overriding Iranian plates that started in the Late Tertiary (Eocene-Recent) and continuing to the present (Numan, 1997) (Ali et al., 2019). The results of this collision are the genesis of the Bitlis-Zagros Fold-Thrust Belt and forming the foreland basin within the Arabian plate. The tectonic deformation has migrated from the line of collision towards the southwest inside Iraq.

\subsection{Fold Analysis}

To study the structural characteristics of Bajalia Anticline, a traverse with northeastsouthwest direction, which is perpendicular to the fold axis, was chosen in the middle of the Anticline as shown in Figure 3. The Anticline is non-cylindrical because it has two culminations and depression in between. The attitudes of numbers of bedding and fracture surfaces were taken by using the geological compass. Based on these values, the stereographic projections of $\mathrm{Bi}$ and Beta diagrams were carried out to classify the Anticline and its fractures.

Figure 8 shows the stereographic projection of Bajalia Anticline. The dip angle of the NE limb is about $40^{\circ}$ and the SW limb about $85^{\circ}$. These values indicate that the Anticline is an asymmetrical fold according to Billings (1972). The interlimb angle is about $55^{\circ}$, which indicates a close fold based on Fleuty (1964). The azimuth of the hinge line is $127^{\circ}$ with a plunge angle of $02^{\circ}$ and these values represent a sub-horizontal fold based on Fleuty (1964). The axial surface has an azimuth of $308^{\circ}$ with a dip angle of $67^{\circ}$, which means that the Anticline is a steeply inclined fold according to Fleuty (1964). The ratio of the length over the width (28/5) of Bajalia Anticline is larger than 5 which indicates a linear fold according to Jaroszewski (1984). Table 1 summarizes the geometrical classification of Bajalia Anticline. Figure 9 represents a geological cross-section in the middle of the Anticline and perpendicular to the hinge line as shown in Figure 3. From the field observations, the bedding plains contain slickensides with clear striations, lines, and steeps. This indicates that the style of folding is a flexural slip, which is persistent vertically. This figure also shows the asymmetry and the vergence at the SW limb of the Anticline.

\subsection{Fractures Analysis}

In geology, fractures include joints, fissures, veins, and faults (Ramsay \& Huber, 1987). This section describes fractures in Bajalia Anticline. Joints can be classified into a joint set and joint system. A joint set is a group of parallel and spaced joints, while a joint system consists of two or more intersecting joint sets (Billings, 1972). The most common joints in the Bajalia Anticline are joint sets. Based on the orientations to an orthogonal system of coordinates $(\mathrm{a}, \mathrm{b}, \mathrm{c})$ related to the fold geometry and the bedding, the joint sets in the study area are the $a c$ and $b c$ types, while the joint system is the hol type. Figure 10 shows the $a c$ and $b c$ joint sets, and hol joint system. The red dotes are the average of poles of joint planes. The green and blue great circles are the NE and SW limbs of the Anticline respectively. Green and blue dotes are poles of the limbs. Fractures parallel to the plane of the $a$ and $c$ axes are called $a c$ fractures, which are the most common in the study area. 


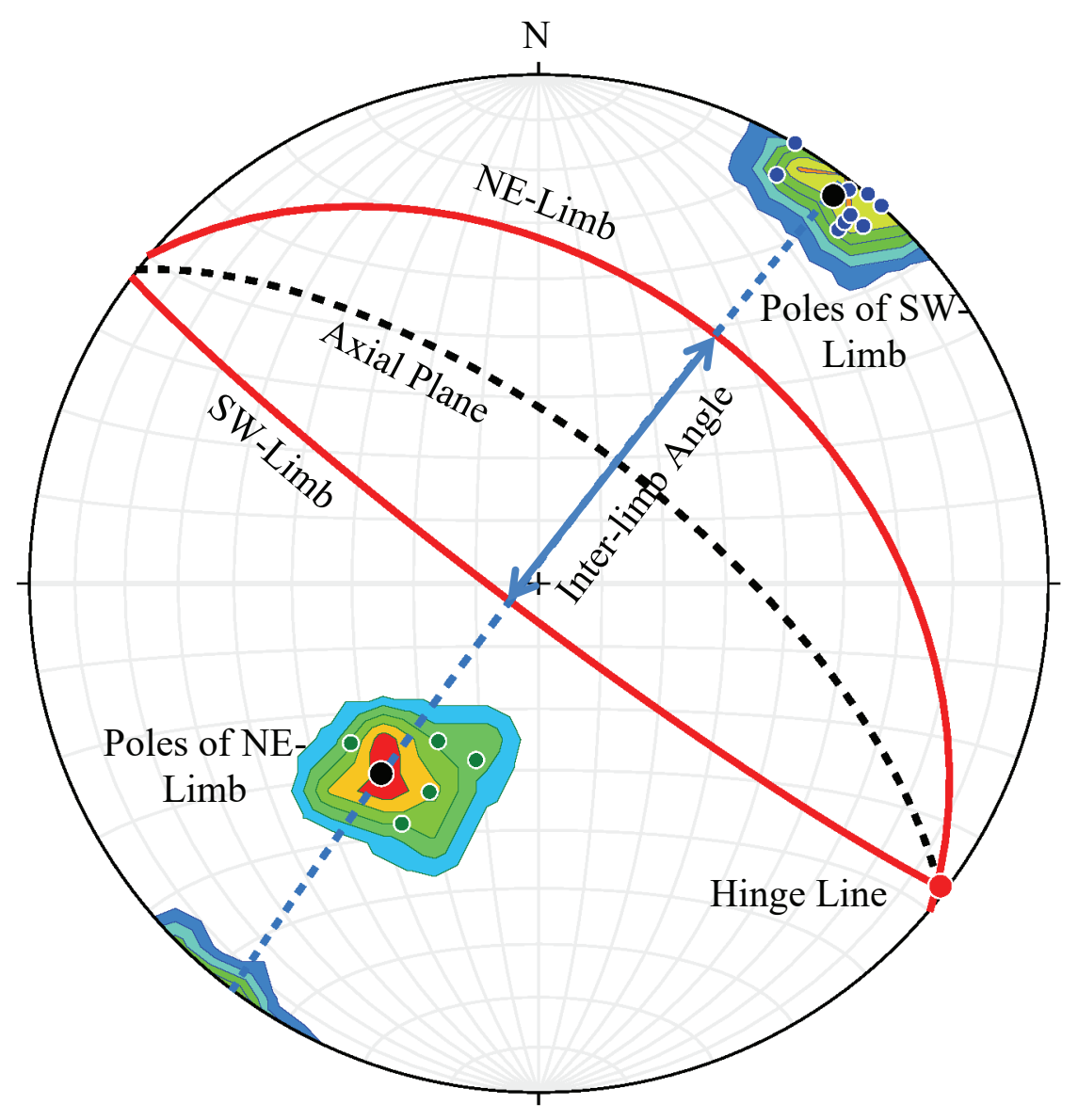

Fig. 8. Stereographic projection of Beta- and Bi-diagrams of Bajalia Anticline using equal-area or Schmidt net.

Table 1. Geometrical classifications of Bajalia Anticline based on the proportion of length over width, the dip angle of limbs, the inter-limb angle, the plunge angle of the hinge line, and the dip angle of the axial surface. In all plane attitudes, the dip azimuth is located clockwise from the strike azimuth.

\begin{tabular}{|c|c|c|c|c|}
\hline $\begin{array}{l}\text { Classification of } \\
\text { Fold }\end{array}$ & Base Elements & Values & $\begin{array}{l}\text { Condition or } \\
\text { Criteria }\end{array}$ & Reference \\
\hline Linear Fold & Length/Width & $28 \mathrm{~km} / 5 \mathrm{~km}$ & Length/Width $>5$ & $\begin{array}{l}\text { Jaroszewski, } \\
1984\end{array}$ \\
\hline Asymmetrical Fold & NE-Limb & $310^{\circ} / 40^{\circ}$ & \multirow{2}{*}{ Different dip angles } & \multirow{2}{*}{ Billings, 1972} \\
\hline & SW-Limb & $127^{\circ} / 85^{\circ}$ & & \\
\hline Close Fold & $\begin{array}{l}\text { Inter-limb } \\
\text { Angle }\end{array}$ & $55^{\circ}$ & $30^{\circ}-70^{\circ}$ & Fleuty, 1964 \\
\hline Sub-horizontal Fold & Hinge Line & $127^{\circ} / 02^{\circ}$ & $1^{\circ}-10^{\circ}$ & Fleuty, 1964 \\
\hline $\begin{array}{l}\text { Steeply Inclined } \\
\text { Fold }\end{array}$ & Axial Surface & $308^{\circ} / 67^{\circ}$ & $60^{\circ}-80^{\circ}$ & Fleuty, 1964 \\
\hline
\end{tabular}




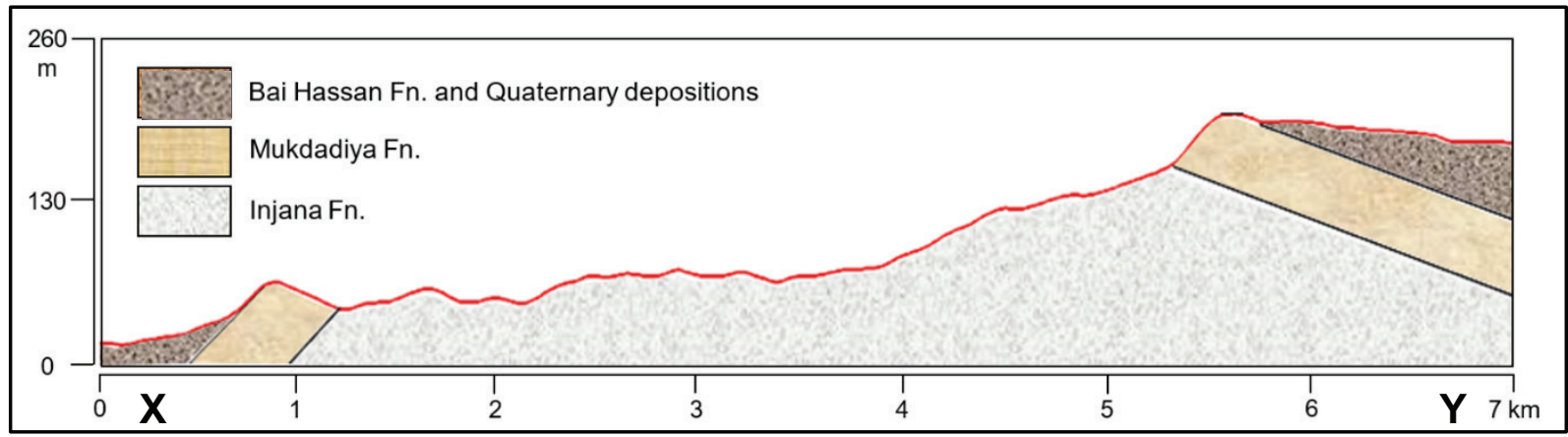

Fig. 9. Geological cross-section through Bajalia Anticline. The X-Y traverse is shown in Figure 3.
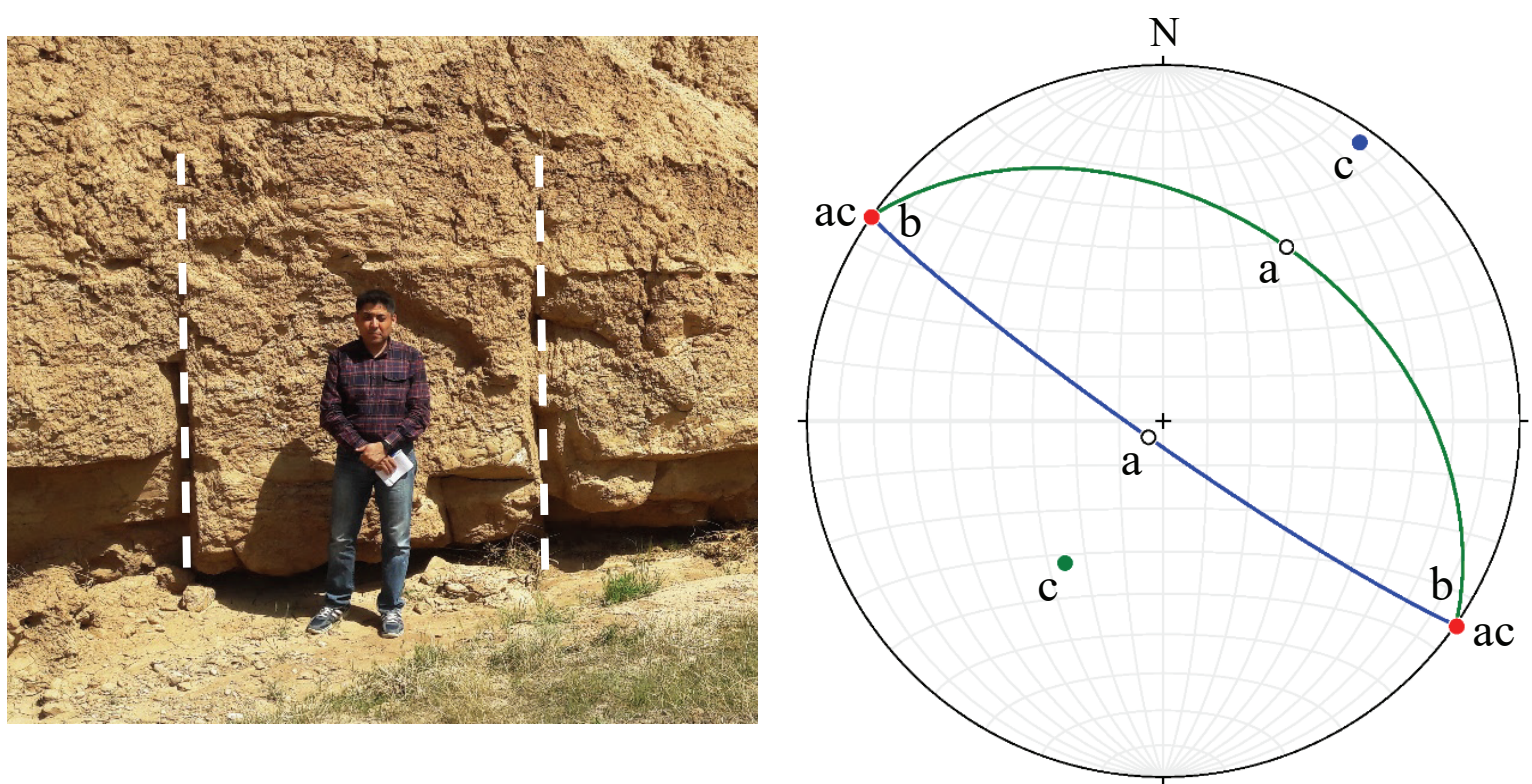

Fig. 10. The left panel is a photo of the ac joints. The right panel is the stereographic projection of mean of ac joint poles (red dotes) and means of two limbs of the Bajalia Anticline. Green great circle and dote are the NE limb. Blue great circle and dote are the SW limb.

\subsection{Basement Fault}

The approximate value to the depth of basement rocks in the study area is found to be about $12 \mathrm{~km}$ below the earth surface

depending on the aeromagnetic map and the Bouger gravity map (C.G.G., 1974 and
Alyasi et al., 2014). The tectonic boundary between the Low Folded Zone and the Mesopotamian Foredeep at the study area is the Mandali-Badra-Amarah fault, which is a basement fault with an NW-SE trend. This fault represents the northeast part of the halfgraben of the Mesopotamian basin. The fault 
is seismically active and many earthquakes with magnitudes reach $5.7 \mathrm{Mw}$ occurred on the fault surface. From the focal mechanism solutions of these earthquakes, the neotectonics movement on the fault surface is reverse movement. The dip angle of the fault is $60^{\circ}$ with a strike line trend of $136^{\circ}$ and dip direction of $226^{\circ}$ (Abdulnaby et al. 2016a and $b)$.

Most of the geologic structures in the study area have been formed because of the stress resulting from the collision between the Arabian and Iranian plates. The compressional forces are the reason behind the reversal movement on the fault surfaces. The reverse faults are usually associated with the anticlines in the folded zone of Iraq and parallel to the fold axes (Numan \& Alazawi 1993) (Zebari et al., 2019). Therefore, Bajalia Anticline that has a reverse fault parallel to the fold axis is a fault-associated fold (see Figure 3).

\subsection{Salt Tectonics}

Salt tectonics also plays a role in forming the subsurface and surface geological structures in the study area (Alyasi et al., 2014). The salt tectonics is represented by evaporite flowage of Fat'ha and/or Gotnia Formations. Hormuz salt Formation does not exist in the study area because it does not pass the Takhaded-Qurna fault, which represents the northern boundary of the Zubair subzone (Abdulnaby, 2003).

According to O'Brien (1957), the stratigraphic column of southwest Iran can be divided into five groups based on their structural and mechanical behavior; these are from bottom to top: (1) the basement group that consists of the Proterozoic igneous and metamorphic basement rocks; (2) the lower mobile group that is represented by the Late Proterozoic-Early Cambrian Hormuz evaporites with about $1 \mathrm{~km}$ thickness; (3) the competent group that consists of Cambrian-
Early Miocene carbonates and sandstones with minor shales and evaporites with total thickness ranges from 6 to $7 \mathrm{~km}$; (4) the upper mobile group that consists of the highly mobile Miocene evaporites known as the Gachsaran Formation in Iran with variable thickness that ranges from a few hundred meters up to $2 \mathrm{~km}$; and (5) the incompetent group that consists of the Late MioceneQuaternary clastic rocks including claystones, sandstones, and conglomerates with highly variable thickness, due to the unstable tectonic conditions during their deposition, which ranges from 3 to $4 \mathrm{~km}$ more frequently.

The model of these groups can be adapted to understand the structural and tectonic evolution of Bajalia Anticline with some modifications. First, the lower mobile group represented by Hurmoz Formation is not existing in the study area. Second, the competent group may contain some local secondary detachment horizons, such as Gotnia Formation that has an obvious effect on the subsurface structures (oilfields) in the study area (Alyasi et al., 2014). Gotnia Formation consists predominantly of massive anhydrites with thin interbeds of shales and limestone (Aqrawi et al., 2010). Therefore, Gotnia Formation can be considered as a mobile group. Third, the upper mobile group in Iraq is represented by the Fat'ha Formation, which is the equivalent of Gachsaran Formation. Fat'ha Formation covers the Mesopotamia Fordeep, Low Folded Zone, and parts of the High Folded Zone (Fouad, 2012). The formation consists of a cyclic alternation of claystones, carbonates, and evaporites that includes gypsum, anhydrite, and halite (rock salt). Fat'ha Formation can be an upper mobile group only if it has sufficient rock salt, which is the case in the study area. Fourth, the incompetent group in the study area is represented by Injana, Mukdadiya, and Bai 
Hassan Formations that are situated above the upper mobile group of Fat'ha Formation.

The two mobile groups of Gotnia and Fat'ha Formations have had provided efficient detachment surfaces allowing the competent and incompetent groups to be folded and faulted independently of each other.

\section{Discussion and Conclusion}

Bajalia Anticline was formed because of the compressional forces during the collisional tectonic set-up of the Arabian and Iranian Plates that started in the Eocene. The Anticline is one of the folds of the Low Folded Zone of Iraq, which is part of the Zagros Fold-Thrust Belt. The three sedimentary formations (Injana, Mukdadiya, and Bai Hassan) that are exposed in the Anticline were deposited inside the foreland basin of the Arabian Plate. These formations were deformed to form the Bajalia Anticline.

The geomorphology of Bajalia Anticline is controlled by the rock properties, dip angles of limbs, and the direction of the seasonal courses. The most common geomorphological units of structural origin are cuestas and hogbacks. The differential erosion in the study area occurs because of the different physical properties of rocks, which are sandstone, siltstone, claystone, and gravel. Most of the crust of the Anticline was eroded and removed which led to exposure to the Injana and Mukdadiya formation and form lithological outcrops to help to study the stratigraphy of the area. Because of that, the two contacts between Injana, Mukdadiya, and Bai Hassan were recognized in Bajalia Anticline. In the SW limb, Bai Hassan Formation is almost eroded totally except in small areas.

The geometrical analysis indicates that Bajalia Anticline is non-cylindrical, asymmetrical, close, sub-horizontal, steeply inclined, and linear fold. The style of folding is a flexural slip, which can be recognized by the bedding plains that contain slickensides with clear striations, lines, and steeps. The asymmetry and the vergence at the SW limb of the Anticline are because of the existence of a reverse fault along this limb. The intensity of folding is high which is indicated by the small inter-limb angle, the vergence, and the overturned beds of Mukdadiya Formation at the middle of the southwestern limb.

The fold axis of Bajalia Anticline trends NW$\mathrm{SE}$, which is the Zagros trend that was formed due to the Alpine orogeny. The compressional stress regime, which has a NE-SW trend, and the thrust fault along the SW limb are believed to be responsible for the difference in elevations of the limbs. The NE limb is much higher than the SW limb that makes Bajalia Anticline lying on a surface tilted toward the southwest.

Fat'ah and Gotnia Formations may play a role in forming the Bajalia Anticline through their behavior as incompetent beds and flow to fold the strata above them. This behavior of evaporites was recognized in the Buzurgan oil field that is very close to the Bajalia Anticline. The salt tectonics might be responsible for the non-cylindrical folding of Bajalia Anticline that has two culminations and depression in between.

\section{ACKNOWLEDGEMENT}

We are grateful to the Groundwater Authority, Ministry of Water Resources, Maysan Governorate for helping and hosting us during the fieldwork days. Also, we would like to express our thanks to the Ministry of Defense, especially the Border Police, for permitting us and supports to reach extreme points at the Iraq-Iran border. 


\section{References}

Abdulnaby, W. (2003) The Structural and Geotectonic of Jabal Sanam, South of Iraq. Msc thesis, College of Science, University of Basrah, 110P.

Abdulnaby, W., Al-Mohmed, R. \&Mahdi, M. (2016b) Seismicity and Recent Stress Regime of Diyala City, Iraq-Iran border. Model. Earth Syst. Environ. 2:142. DOI $10.1007 / \mathrm{s} 40808-016-0201-\mathrm{z}$

Abdulnaby, W., Mahdi, M., Al-Mohmed R., \& Mahdi, H. (2016a). Seismotectonics of Badra-Amarah Fault, Iran-Iraq Border. IOSR Journal of Applied Geology and Geophysics (IOSR-JAGG), 4(3): 27-33.

Al-Abadi, A. (2011). Hydrological and Hydrogeological Analysis of Northeast Maissan Governorate, South of Iraq Using Geographic Information System. Ph.D. dissertation, Department of Geology, College of Science, University of Baghdad.

Al-Abadi, A. (2015). Groundwater Potential Mapping at Northeastern Wasit and Missan Governorates, Iraq Using a Data-driven Weights of Evidence Technique in Framework of GIS. Environ Earth Sci. doi:10.1007/s12665-015-4097-0.

Al-Dousari, A. M., \& Al-Awadhi, J. (2012). Dust fallout in Northern Kuwait, major source and characteristics, Kuwait journal of Science, 39 (2A), 171- 187.

Ali, S.A., Nutmana, A.P., Aswad, K.J., \& Jonesa, B.G (2019). Overview of the tectonic evolution of the Iraqi Zagros thrust zone: Sixty million years of Neotethyan ocean subduction. Journal of Geodynamics. 129:162-177.
Al-Muturi, W. G. \& Al-Asadi, M. M. (2008). Tectonostratigraphic History of Mesopotamian Passive Margin during Mesozoic and Cenozoic, South Iraq, journal of Kirkuk University - Scientific Studies, vol.3, No.1: 31- 50.

Al-Rawi Y, Sayyab, A., Al-Jassim, J., Tamar-Agha, M., Al-Sammarai, A., Karim, S., Basi, M., Hagopian D., Hassan, K., Al-Mubarak, M., Al-Badri, A., Dhiab, S., Faris, F. \& Anwar, F. (1992). New Names for Some of the Middle Miocene Pliocene Formations of Iraq (Fatha, Injana, Mukdadiya and Bai Hassan formations). Iraqi Geol. Jour. 25(1): 1-17.

Alsaad, H. (2014). Mineralogy and Geochemistry of Claystone of the Injana and Mukdadiya Formations in Selected Areas Eastern Maysan and Wasit and Their Assessment for Normal and Lightweight Bricks Industry. Ph.D. dissertation, University of Basrah, 220P.

Alsamaani, J. (2011). Mineralogy and Geochemistry of Sandstone of AlMukdadiya Formation, Selected Area, NE Maysan. MSc thesis, University of Basrah, $116 \mathrm{P}$.

Alyasi, A., Al-Jawad, S. \& Alshabender, L. (2014). Geophysical Study to the Role of Salt in Creating Buzurgan Oilfield Structure, Southeast of Iraq. Iraqi Journal of Science, 55(4) : 1579-1587.

Ameen, M. S. (1979). Regional Investigation of Geoflexures and Tectonic Analysis in the Simple Folded Zone of Iraq. M.Sc. thesis, Univ. of Mosul, 236. 
Aqrawi, A., Göff, J., Horbury, A. \& Sadooni, F. (2010). The Petroleum Geology of Iraq. Scientific Press: 424P.

Barwari, A. (1991). The Geology of Mandli Quadrangle Sheet (NI-38-11), Scale 1:250000, GEOSURV, lib. Report No. 2227, Baghdad, Iraq.

Barwari, A., Slaiwa, A., Hamza, M., \& Dommas, J. (1993). Geological Map of Ali Al-Gharbi Quadrangle Sheet NI-38-16, Scale 1:250000, GEOSURV.

Bellen, R., Dunnington, H., Wetzel, R., \& Morton, D. (1959). Lexique Stratigraphic International. Asie, Fasc. 10a, Iraq, Paris.

Billings, M. (1972). Structural Geology. 3rd. ed., New Delhi Prentice-Hall, Inc., 606P.

Buday, T. \& Jassim, S. (1987). The Regional Geology of Iraq: Vol.2 Tectonism, Magmatism and Metamorphism. S.E. Geological Survey and Mineral Investigation, Baghdad, Iraq: 352.

C.G.G. (1974). Aeromagnetic and Ariospectrometric Survey of Iraq, GEOSURVY, Internal report.

Fleuty, M. (1964). The Description of Folds. Proceedings of the Geological Association, Vol. 75 (4): 461-489.

Fouad, S. (2012). Western Zagros FoldThrust Belt, Part I: The Low Folded Zone. Iraqi Bulletin of Geology and Mining, Special Issue,5: 39-62.

Fouad, S. (2015). Tectonic Map of Iraq scale 1:1000 000, 3rd ed., 2012. Iraqi Bulletin of Geology and Mining, 11(1): 1-7.

Jaroszewski, W. (1984). Fault and Fold Tectonics. Chichester [W. Sussex]: E. Horwood. New York: Halsted Press: 340.
Jassim, S. \& Göff, J. (2006). Geology of Iraq. Dolin, Prague and Moravian Museum, Brno., 344.

Jassim, S., Karim, S., Basi, M., AlMubarak, M., \& Munir, J. (1984). Final Report on the Regional Geological Survey of Iraq, Vol. 3, Stratigraphy. GEOSURV, int. rep. no. 1447.

Leturmy, P. \& Robin, C. (2010). Tectonic and Stratigraphic Evolution of Zagros and Makran during the Mesozoic - Cenozoic. Geol. Soc., Sp. Pub: 330.

Numan, N. (1984). Basement Control of Stratigraphy Sequences and Structural Pattern in Iraq. Jour. Geol. Soci. Iraq, 16: 824.

Numan, N. \& Al-Azzawi, N. (1993). Structural and Geotectonic Interpretation of Vergence Directions of Anticlines in the Foreland Fold of Iraq. Abhath Al-Yarmouk, Pure Science and Engineering, Yarmouk University, Jordan, 2(2): 22-35.

Numan, N. (1997). A Plate Tectonic Scenario for the Phanerozoic Succession in Iraq, J. Geol. Soc. Iraq, 30(2): 85-110.

Numan, N. (2000). Major Cretaceous Tectonic Events in Iraq. Raf. Jour. Sci., 11(3): 32-52.

O'Brien, C. (1957). Salt Diapirism in South Persia (Iran). Geologie en Minjnbouw, 19: 357-376.

Ramsay, G. \& Huber, M. (1987). Modern Structural Geology. Academic Press; 1st edition, London, UK: 391.

Sissakian, V. \& Al-Jiburi, B. (2014). Stratigraphy of the High Fold Zone. Iraqi 
Bull. Geol. Min., Special Issue, No.6: 73161.

Yacoub, S. (1993). The Geology of AlAmara Quadrangle, Report, No.2324, GEOSURV library, Baghdad, Iraq.

Submitted: $\quad 08 / 07 / 2020$

Revised: $\quad 08 / 10 / 2020$

Accepted: $\quad 07 / 11 / 2020$

DOI: $\quad 10.48129 / \mathrm{kjs} . v 48 \mathrm{i} 4.10108$
Zebari, M., Grützner, C., Navabpour, P., \& Ustaszewski, K. (2019). Relative timing of uplift along the Zagros Mountain Front Flexure (Kurdistan Region of Iraq): Constrained by geomorphic indices and landscape evolution modeling. Solid Earth, 10(3):663-682. 